\title{
Trends In Rare Book Library Facilities
}

\author{
By WILLIAM J. NYE
}

IN 1928 Frank K. Walter, librarian of the University of Minnesota, read a paper before the American Library Institute at West Baden, Indiana. Later to have great historic significance in the development of rare book libraries in the United States, this paper was published the same year in the Library Journal under the title "Safeguarding Rare and Expensive Books in University and Reference Libraries."1

Walter wrote of fireproof vaults, separate rooms, locked cases of metal and wood, special wired-off sections of the book stacks, and special cases in the librarian's office. He closed his discussion with a plea to "strive to give those books better attention than they are now getting as a regular thing."

Many university and research libraries have initiated or expanded rare book programs since Walter made his historic plea. Since 1940 at least twenty major research libraries have added rare book facilities of some kind. Dr. Byrd has suggested that this renaissance of interest in rare book libraries has come about for a number of reasons:

... the practice of open stack access for students and staff has made it imperative to protect from this great body of users the more expensive, hard to replace, and fragile books, that, by accretion, are in the general collection of all university libraries. Material which may or may not be in the rare class such as broadsides, prints, charts, plans, maps, pictures, etc., does not admit of the standardized treatment given conventional books. . . . Segregation for protection, processing, and storage has resulted. ${ }^{2}$

The terms "rare books" and "rare book

1 LIII (September 15, 1928), 733-38.

2 Cecil K. Byrd, "Rare Books in University Li. braries," Library Trends, V (April 1957), 441.
Mr. Nye is Special Collections Librarian, Illinois State Normal University.

collections" will be used in this article to include the whole realm of rare book research libraries, special collections, and rare book collections.

In 1961, while making plans for rare book quarters at Illinois State Normal University, the writer found only a limited amount of material in the library literature. For additional help, a questionnaire was sent to seventy public, college, university, and special libraries. In addition, aid was sought from the Library Technology Project. The answers received from this questionnaire form the basis for this article. Its purpose is to state the present trends in facilities to care for library materials which require special handling and storage and have come to be designated by the generic term "rare books." It is hoped that libraries planning similar facilities may be able to benefit from the material that has thus been gathered and organized and is reported here.

What kind of quarters do rare book rooms occupy? Are there general statements that can be made? What, if any, are the trends? Perhaps the most prominent example of what can be done by combining the latest architectural advances and the best in library technology is the new rare book library to be completed at Yale University in $1963 .^{3}$ This building will feature a six-story shaft with a capacity of 180,000 volumes. Storage stacks in the basement will bring the total capacity to 820,000 volumes. All stacks will be linked by book lift,

3 "New Rare Book Library for Yale," Library Journal, LXXXV (December 1, 1960), 4337. 
pneumatic tube, and tunnel to Yale's Sterling Library. Beneath the stacks will be the library's "working heart"-a research center containing a central control desk, offices, workrooms, reading, and seminar rooms. The building will harmonize with the Gothic-Classical buildings which surround it. ${ }^{4}$

This, however, is not typical of rare book facilities. At the other extreme many libraries reported that only limited facilities-perhaps a wired-off corner of the stacks - were available. Less than one half of the thirty-two responding libraries reported having more than three rooms in their quarters. The Library of Congress reported forty-one rooms; John Carter Brown library had nineteen, and the Free Public library at Philadelphia, eighteen. Five libraries had only one room for their collection. In general, the institutions with more recently established quarters had fewer rooms. Many of the libraries indicated that plans were being drawn at their institutions for new libraries with more adequate rare book quarters.

Decorative schemes within the quarters housing rare books are Modern, Traditional, Georgian, Italian Renaissance - to name the schemes most frequently mentioned. The trend appears to be toward Modern decor in the institutions of the west and the middle west.

The Lilly library at Indiana University has succeeded in having planned the decor of individual rooms to enhance the collections. The Lincoln Room has a patterned damask on the walls which "has been copied from a damask which hung in the White House during President Lincoln's occupancy. . . . The furnishings ... are of the Lincoln era and include an authenticated desk which was used by Mr. Lincoln in Springfield from 1841 to $1844 . " 5$

In twenty libraries informal furniture

\footnotetext{
“ "Rare Building for Rare Books," Architectural Forum, CXIII (November 1960), 139.41.

Indiana University. The Lilly Library. Dedication of the Lilly Library (Bloomington, Indiana: Indiana University, October 3, 1960) [pp. 4-5].
}

- occasional chairs, sofas, or coffee tables -were used. Informal notes appended to the replies to the questionnaires indicated an awareness of the need for a gracious, hospitable mood or atmosphere and that facilities for entertaining guests - perhaps potential donors-should be considered in planning quarters.

Almost all libraries reported using both wooden and metal shelves. There seemed to be no clear-cut preference for wall shelves or free-standing shelves. Twenty-six libraries used free-standing shelves and twenty-eight used wall shelves. Twenty used both wall and freestanding shelves. One correspondent quoted the head of the department of conservation of the British Museum as stating that wooden shelves are to be preferred because they react to atmospheric changes and thus protect the books. Metal shelves, on the other hand, apparently do no react well to atmospheric changes.

Thirteen libraries use glass bookcases to protect the books from dust, atmospheric pollution, theft, and moisture. Seven libraries use metal grills to protect the bookshelves. Glass appears to be preferred if the air is polluted and grillwork if the air is not polluted.

Sixteen libraries reported using tile floors and ten libraries wooden floors. Concrete, especially concrete covered with linoleum, was quite popular as a floor covering. Eleven of the thirty-two responding libraries reported using rugs on most of their floors. These libraries were: John Carter Brown, William L. Clements, Colby College, University of Colorado, Dalhousie University, Detroit Public, Duke University, Free Library of Philadelphia, Indiana University, University of Kentucky, and University of North Carolina. Several librarians mentioned the value of rugs in absorbing sound, in protecting the books by reacting to atmospheric changes, and in providing dignity and atmosphere.

Twenty libraries reported using wall 
exhibit cases, twenty-nine used museum exhibit cases, and seventeen reported using both wall and museum exhibit cases. The following libraries, among others, reported using museum cases only: John Carter Brown, William L. Clements, Library of Congress, University of Illinois, Library Company of Philadelphia, and New York Public.

Ellen Shaffer, rare book librarian, the Free Library of Philadelphia, explained why she believes that wall cases are generally unsatisfactory:

The Free Library of Philadelphia has fifteen flat-top exhibit cases. These I feel are particularly satisfactory for exhibit purposes, as they allow rare materials to be displayed with a minimum of strain. Upright cases are indeed attractive looking, but supporting books in such cases is sometimes unsatisfactory. A great many of these upright cases have sliding glass doors. We have had experience with this type of sliding door, and we find that it admits far more dust and dirt than anyone would believe possible. Also on occasion these glass doors interfere with each other and chip. ${ }^{6}$

Basil Stuart-Stubbs, head, special collections, University of British Columbia, added a word of caution on the problems of exhibiting rare books in libraries:

... Watch the design of exhibit cases carefully: no artificial lighting of any kind unless air conditioning is adequate. Reason: if you bring a book from 50 per cent humidity into a warm and dry exhibit case you will buckle the covers. The light does wonders for that red morocco, but it also ruins the book. ${ }^{7}$

Reports revealed that only seven libraries-University of California (Berkeley), Library of Congress, Detroit Public, Duke University, Free Library of Philadelphia, Indiana University, and New York Public-have facilities for binding and repair within the rare book quarters. Only six libraries-John Carter Brown, Colby College, Indiana University, Mc-

Letter, November 13, 1961.

\% Letter, November 21, 1961.
Gill University, University of Mississippi, New York Public, and University of Toronto-have facilities for photoduplication services within the rare book quarters. Most libraries reported using central library facilities to bind and repair materials, or that needed work was done by a commercial service. Almost all libraries reported that photoduplicating services were available in the central library. About one-third reported having storage shelves in the workroom, two-thirds had cabinets, two-thirds had sinks, and nearly all had typewriters.

Frazer G. Poole, director, Library Technology Project, has stated that "If the collection is likely to grow to some size a small adjacent workroom may be desirable in order that bindings may be treated and minor repairs made without removing the materials from the area." 8 Most librarians were not as conservative in statement as Mr. Poole, however. Some libraries reported entrusting fragile materials to central library facilities or commercial services and having the materials returned much the worse for their experience. General sentiment favored large workrooms with specialized equipment and staff to handle the special materials.

Rare books, wherever housed, require constant protection from the enemies of books-fire, water, insects, dust, humidity, excessive temperatures, light, thieves, and destructive users. Howard H. Peckham, director, William L. Clements library, points out the characteristics of materials in a rare book collection that make conservation methods necessary:

It is expensive. The average cost of each book added to a public library is about four dollars; to a university library, about six dollars. The price paid per acquisition at the William L. Clements library last year (1956) averaged \$92; at the John Carter Brown library, \$97. These figures are unexceptionable and probably are exceeded by a few other institutions.

\footnotetext{
${ }^{8}$ Letter, November 9, 1961.
} 
It is so scarce as to be difficult or impossible of replacement. Two copies of a book are not bought in the first acquiring of a title, and reordering in case of a loss is useless. Manuscript items are, of course, unique.

More than text is important. Rare books may be prized for their pictures or maps, for their binding or association, for their printer or place of publication, for their scarcity or other factors. Priority puts a premium on first editions. In such libraries it does make a difference in what form a text reaches their shelves.

Compared to modern publishing output and the size of city libraries, material eligible for inclusion in a rare book library is small in quantity. Usually it has been sifted by generations of scholars and collectors. A rare book library, therefore, is almost never a big library. ${ }^{9}$

Twenty-nine libraries reported that the walls of their quarters were fireproof, twenty-two used a fire alarm system, and eighteen reported having both fireproof walls and a fire alarm system. One of the outstanding examples of making a library as fireproof as possible is the Newberry library. The following features are incorporated as protective devices:

1. Controls for smoke and heat detection.

2. A system of compartmentation insuring that a fire will not involve more than ten per cent of the building.

3. Rewiring and replumbing.

4. Automatic Detection Telegraph Service.

5. Agreement with the fire department not to use water.

Seven libraries-Detroit Public, University of Florida, Free Library of Philadelphia, Washington University, New York Public, University of Kentucky, and University of Kansas-reported having fumigation facilities in the rare book quarters. Such facilities in the rare book rooms are relatively scarce because insects are not a problem in most of the libraries reporting or because commer-

\footnotetext{
"Introduction to Rare Book Libraries and Collec. tions," Library Trends, V (April 1957), 417-18.
}

cial services are adequate in those areas where infestation by insects is a problem.

Sixteen libraries reported maintaining a constant relative humidity: one at 3550 per cent; one at $40-60$ per cent; one at 45 per cent; two at $45-50$ per cent; eight at 50 per cent; one at $50-55$ per cent; one at 54 per cent; and one at 67 per cent. Preference here is clearly shown for a relative humidity of about fifty per cent. Several libraries reported housing their collections in the basement as the humidity and temperature there were more constant. One library reported maintaining a constant temperature of $65^{\circ}-75^{\circ} \mathrm{F}$; three of $68^{\circ} \mathrm{F}$; one of $68^{\circ}-70^{\circ} \mathrm{F}$; seven of $70^{\circ} \mathrm{F}$; one of $70^{\circ}-75^{\circ} \mathrm{F}$; four of $72^{\circ} \mathrm{F}$; two of $75^{\circ} \mathrm{F}$; and one of $75^{\circ}-85^{\circ} \mathrm{F}$.

Twenty-three libraries reported having air conditioning; fifteen have both air conditioners and air filters. Both the Lilly library at Indiana University and the Harry S. Truman library have electrostatic filter systems, the Lilly library throughout and the Harry S. Truman library in the rare book room.

Five libraries-John Carter Brown, Lilly, New York Public, St. Louis University, and Washington Universityreported using burglar alarms. Other libraries reported that frequent checks by watchmen made burglar alarms unnecessary.

Howard H. Peckham has made certain observations about the way rare book libraries maintain security by screening potential readers:

Use is restricted. Circulation outside the building is never permitted, and reading rooms are supervised. Cautions are given about handling rarities. Readers have to identify themselves and sometimes prove their competence by deposing that they have exhausted the secondary materials on their subject. Since most of the patrons are doing research, a very high percentage of them are scholars, as distinguished from the lay public and children. ${ }^{10}$

Georgia C. Haugh, curator of printed ${ }^{10} \mathrm{Ibid}$. 
books, William L. Clements library, has explained other ways in which rare book libraries seek to maintain security of their collections when they are being used by readers:

All rare book libraries shelve their collections in locked stacks, or locked cases, or locked cases in locked stacks; often the greatest rarities are kept in special vaults, or "vault rooms." Reference works, however, are found often in open areas with easy access by the reader. . . . Occasionally a trustworthy reader with special requirements will be taken to the shelves by a staff member. Any photographing of materials is arranged by the staff. Smoking is prohibited in reading areas. ${ }^{11}$

Twenty-four of the thirty-two responding libraries permitted readers to read in the rooms where the books are housed. This relationship is no doubt limited in most cases to the less rare books, yet even these are usually covered with a grill or encased in glass. Too, the reading room is usually attended by a staff member.

A number of librarians referred to the care that should be taken, especially in exhibit cases, to use proper fluorescent lights. Document glass was recommended for exhibit cases.

Protection of books in the event of enemy attack is a concern of many libraries. The Lilly library is equipped with two large vaults, both bombproof. Transfer of records vital to national security could be necessary to insure continuity of government in case of a bomb attack.

A large majority of rare book collections are now being housed in quarters not originally designed for that purpose. Most rare book collections are housed in buildings built when little was known of library technology for conventional materials and even less was known of the specialized facilities needed for the care of what we now regard as "rare books."

No substantial body of literature exists

11 "Reader Policies in Rare Book Libraries," Library Trends, V (April 1957), 472. to guide the library planner in his quest to learn of the appropriate facilities for the care of rare books. Librarians with experience and success in planning rare book libraries have apparently not published in this area. As a consequence, less experienced rare book librarians have had to depend upon the resources of informal professional associations and the examination of established rare book libraries. In the responses to the questionnaire used in this study, the author noted the emergence of definite and generally accepted principles of rare book library facilities current in the library world today.

Principles of planning for the care of nonconventional library materials overlap a great deal with the principles for caring for conventional materials. There is a concern for durability, utility, beauty, security, and, more recently, flexibility.

Traditionally, rare book libraries have placed a heavy emphasis on beauty and security. The net result of this overemphasis has created an imbalance in rare book library facilities. Libraries of great aesthetic appeal offering splendid protection for their collections have been established. Unfortunately, many of these libraries have existed more as showpieces to enhance the image of an institution rather than as agencies to serve the needs of the scholars who use the books which they contain.

The trend now, however, is toward greater balance in libraries without a resultant loss of security or reduction in dignity. Almost all libraries are trying to provide more workroom facilities to care for the cataloging, conservation, restoration, and photoduplication needs of their collections. A change in library philosophy toward greater concern for the problems of the reader has caused libraries to plan more space for readers to study rare materials and to consult bibliographical works auxiliary to the collection. 
Recently established rare book libraries are attempting to provide facilities in keeping with the needs of the institutions that they serve rather than trying to model their libraries after the pattern of the established rare book libraries of great tradition and prestige.

Security has continued to be a prominent concern, but the harsh, metallic, security "machinery" so often offensive to library patrons is being replaced by an acceptance of the qualified patron as a partner in the intellectual quest. The rare book librarian is becoming less of a proprietor and more of a gracious host.

Grounds for encouragement in the development of rare book library facilities are many. Optimism prevailed throughout the responses to the questionnaire. Even those librarians with the most in- adequate facilities were eagerly making ambitious plans for the day when new library building plans would make possible more desirable quarters and specialized equipment. The Library Technology Project is making materials and equipment standards available to the library profession. Much of this information will prove most helpful to the rare book librarian.

A close liaison with archivists, museum curators, and business records management specialists should be mutually beneficial. The establishment of courses in library schools dealing with the problems of rare book library facilities would be most appropriate. Increased publication by rare book librarians in the problems of rare book library facilities is sorely needed.

\section{ALA Representatives at Academic Ceremonies}

ALA REPRESENTATIVES at recent academic ceremonies were: Joseph Reason, ACRL executive secretary, at the dedication of Trinity College library, Washington, D.C. on May 31; Oivind M. Hovde, libarian, Luther College, Decorah, Iowa, at the inauguration of Elwin D. Farwell as president of the college on May 11; Margaret M. Kinney, chief librarian, U.S. Veterans Administration Hospital library, at the inauguration of Rosemary Park as president of Barnard College on April 22; Bernard Kreissman, librarian of City College of the City University of New York, at the Charter Centenary of Manhattan College on April 20; Gustave Harrer, director of Boston University libraries, at the Centennial Convocation of that university on April 20; Bruce M. Brown, librarian, Colgate University, Hamilton, N.Y., at the inauguration of Vincent MacDowell Barnett, Jr., as president of the university on April 19; William D. Joyce, librarian, Massachusetts State College at Worcester, Mass., at the inauguration of Clifton Woodford Emery, Jr., as president of Worcester Junior College on April 8; Ned C. Morris, acting librarian, Texas College of Arts and Industries, Kingville, Tex., at the inauguration of James Coffey Jernigan as president of the college on March 25; and Yuan Tao-Feng of Long Island University at the inauguration of Ralph Gordon Hoxie as president of C. W. Post College of the university, on December 16. 